\title{
THE INFLUENCE OF SELF CONCEPT, ACHIEVEMENT MOTIVATION, AND LEARNING STYLE TOWARD MATHEMATICS DISPOSITION AND MATHEMATICS LEARNING RESULTS OF GRADE XI STUDENTS AT SMAN IN MAKALE CITY
}

\author{
Ersi Cresli ${ }^{1)}$, Arif Tiro ${ }^{2)}$, Suwardi Annas ${ }^{3)}$ \\ ${ }^{1}$ Pendidikan Matematika PPs Universitas Negeri Makassar, email: ersicresli@gmail.com \\ ${ }^{2,3}$ Prodi Pendidikan Matematika PPs Universitas Negeri Makassar, Indonesia
}

\begin{abstract}
High learning result in Mathematics is a benchmark of students' success in Mathematics learning. The students need positive characters and attractiveness to achieve high learning results in Mathematics. Moreover, the students need self concept, achievement motivation, and learning style as well. The research aims at examining the extent of the influence of self concept, achievement motivation, and learning style toward mathematics disposition and the students mathematics learning results in Mathematics of grade XI students at SMAN (public senior high schools) in Makale city. The research is ex-post facto. The populations of the research were the students of grade XI at SMAN in Makale city. The samples were obtained by using cluster proportional random sampling with the total of 171 students. The data collection technique employed self concept questionnaire, achievement motivation questionnaire, learning style questionnaire, mathematics disposition questionnaire, and mathematics learning results test. The data of the research was analyzed by using descriptive and multiple regression analysis. The results of the research reveal that: (1) most students of grade XI at SMAN in Makale city have self concept, achievement motivation, mathematics disposition and mathematics learning results, which is in medium category and visual learning style; (2) self concept has positive influence toward mathematics disposition with contribution $28.9 \%$ and give no positive influence toward mathematics learning results with contribution $2.5 \%$. Achievement motivation has positive influence toward mathematics disposition with contribution $47.2 \%$ and give no positive influence toward mathematics learning results with contribution $14.9 \%$. There is no influence of learning style both toward mathematics disposition and mathematics learning results. Self concept, achievement motivation, and learning style collaboratively explain approximately $51 \%$ of mathematics disposition variation and $2 \%$ of mathematics learning results variation. After the development of discussion, self concept gives contribution $15 \%$ toward mathematics learning results through mathematics disposition.
\end{abstract}

Keywords: Self Concept, Achievement Motivation, Learning Style, Mathematics Disposition

\section{PENDAHULUAN}

Pendidikan memegang peranan yang sangat penting dan sudah menjadi kebutuhan manusia. Proses pendidikan sesungguhnya telah berlangsung semenjak manusia dilahirkan. Dengan adanya pendidikan, seseorang diharapkan mampu memperbaiki taraf hidupnya. Pendidikan merupakan salah satu program pemerintah untuk menyejahterakan masyarakat. Kemajuan suatu bangsa ditentukan oleh tingkat keberhasilan pendidikan. Keberhasilan pendidikan akan tercapai apabila ada usaha untuk meningkatkan mutu pendidikan bangsa itu sendiri. 
Pendidikan adalah usaha sadar yang dilakukan untuk mengembangkan kemampuan dan kepribadian individu melalui proses atau kegiatan tertentu (pengajaran, bimbingan atau latihan) serta interaksi individu dengan lingkungannya untuk mencapai manusia seutuhnya (Arifin, 2011). Fungsi dan tujuan pendidikan nasional menurut pasal 3 UU No. 20 Tahun 2003 (Hartuti, dkk, 2012) menyatakan bahwa:

"Pendidikan nasional berfungsi mengembangkan kemampuan dan membentuk watak serta peradaban bangsa yang bermartabat dalam rangka mencerdaskan kehidupan bangsa, bertujuan untuk berkembangnya potensi peserta didik agar menjadi manusia yang beriman dan bertakwa kepada Tuhan Yang Maha Esa, berakhlak mulia, sehat, berilmu, cakap, kreatif, mandiri dan menjadi warga negara yang demokratis serta bertanggung jawab."

Tujuan-tujuan tersebut terkadang sulit tercapai karena perilaku siswa yang sering menyimpang. Misalnya, menyontek saat ujian hanya untuk mendapatkan nilai yang tinggi saja tetapi sebenarnya mereka tidak mengerti.

Matematika merupakan mata pelajaran yang dipelajari mulai dari pendidikan dasar sampai pendidikan yang sangat tinggi. Dengan belajar matematika, kita akan belajar bernalar dengan kritis, kreatif dan aktif. Menurut Suheman, dkk (2003) fungsi matematika adalah sebagai alat untuk memahami atau menyampaikan informasi misalnya melalui suatu persamaan atau tabel-tabel dalam model-model matematika, pola pikir (mengasah cara berpikir atau daya nalar dalam memahami suatu konsep atau hubungan antar berbagai konsep), dan ilmu pengetahuan (matematika selalu mencari kebenaran dan bersedia meralat kebenaran yang sementara diterima bila ditemukan kesempatan untuk mencoba mengembangkan penemuan-penemuan sepanjang mengikuti pola pikir yang sah).

Namun pada kenyataannya, masih banyak orang yang beranggapan bahwa matematika itu sangat sulit. Hal ini disebabkan oleh banyak faktor seperti cara mengajar guru yang monoton, dan perilaku siswa yang cepat menyerah bila diperhadapkan pada soal-soal yang sulit.

Menurut Wardani (2013) bahwa salah satu indikator yang menunjukkan mutu pendidikan di Indonesia cenderung masih rendah adalah hasil penilaian internasional tentang hasil belajar siswa. Survei Trends International Mathematics and Science Study (TIMSS) pada tahun 2009 menempatkan Indonesia pada peringkat 61 dari 65 peserta.

Berdasarkan hasil observasi dan wawancara dari guru di salah satu SMAN di kota Makale yang menyatakan bahwa budaya menyontek di kalangan pelajar masih sangat tinggi dan sikap siswa yang tidak etis. Hal ini sejalan yang dikemukakan oleh Suciati (2013) bahwa faktor-faktor yang mempengaruhi pencapaian hasil belajar siswa yaitu berasal dalam diri siswa atau faktor psikologi (misalnya konsep diri, motivasi berprestasi, gaya belajar, dan lain-lain) sehingga dapat membentuk karakter yang lebih mampu merespon positif setiap perubahan siswa.

Disposisi matematis merupakan salah satu faktor yang ikut menentukan keberhasilan belajar siswa. Menurut Mahmudi (2010) disposisi matematika merupakan ketertarikan, aspresiasi dan sikap positif siswa terhadap matematika. Dengan adanya disposisi matematika dalam diri siswa, mereka akan 
gigih menghadapi masalah yang lebih menantang, bertanggung jawab terhadap diri mereka sendiri, dan mengembangkan kebiasaan baik pada matematika.

Hasil observasi dengan guru di salah satu SMA Negeri di Kota Makale menyatakan sekitar $75 \%$ siswa tidak mencapai KKM pada mata pelajaran matematika. Hal ini disebabkan oleh sikap siswa yang tidak memiliki ketertarikan terhadap matematika, siswa sering membenci mata pelajaran matematika karena pelajarannya sulit dimengerti, mempunyai rumus-rumus yang terlalu banyak sehingga mudah dilupa dan cara pengerjaan soal yang sangat sistematis.

Menurut Saam dan Wahyuni (2012) konsep diri sangat berpengaruh terhadap tingkah laku individu. Konsep diri yang dimiliki seseorang akan turut menentukan bagaimana ia menerima, merasakan, dan merespon lingkungannya. Bila ia menilai dirinya kurang baik, maka ia akan menganggap remeh dan membayangkan kegagalan usahanya, sedangkan individu yang menilai dirinya baik atau positif maka ia akan bersifat optimis terhadap usahanya dan berusaha mengatasi kesulitannya, sehingga bertambah kemungkinannya untuk sukses.

Setiap individu akan memiliki konsep diri yang positif atau negatif dengan intensitas yang berbeda-beda. Bila seseorang mempunyai konsep diri positif, maka ia lebih memiliki keyakinan bahwa ia mampu melakukan tugas tertentu sehingga mendorongnya untuk mencapai keberhasilan, sedangkan seseorang yang mempunyai konsep diri negatif cenderung mempunyai harapan yang rendah terhadap keberhasilan usahanya (Saam dan Wahyuni, 2012). Hal tersebut juga sesuai dengan penelitian yang dilakukan oleh Ayodele (2011) pada siswa SMA di Nigeria bahwa siswa dengan konsep diri yang tinggi dan positif menunujukkan hasil belajar matematika yang memuaskan.

Motivasi adalah sesuatu yang mendorong, atau pendorong seseorang bertingkah laku untuk mencapai tujuan tertentu (Saam dan Wahyuni, 2012). Motivasi ditinjau dari pihak yang menggerakkan motivasi terdiri dari dua golongan, yaitu motivasi intrinsic dan ekstrinsik. Motivasi intrinsik adalah motivasi yang berasal dari dalam diri orang tersebut, misalnya seorang mahasiswa belajar dengan kesadaran sendiri tanpa disuruh orang lain. Individu tersebut memperoleh kepuasan dengan proses belajar itu sendiri. Motivasi ekstrinsik adalah motivasi yang berfungsi karena danya dorongan dari pihak luar atau orang lain, misalnya seseorang belajar karena disuruh oleh orang tua, teman atau kakaknya.

Dari sekian banyak motivasi, motivasi berprestasi memiliki peran yang penting dalam kehidupan manusia. Motivasi berprestasi adalah motivasi untuk berhasil dalam melakukan suatu tugas atau pekerjaan (Uno, 2012). Motivasi berprestasi sangat berpengaruh terhadap unjuk kerja seseorang, termasuk dalam belajar.

Faktor afektif lain yang biasa mendukung siswa dalam mencapai hasil pembelajaran matematika adalah gaya belajar. Menurut Deporter (2003) gaya belajar seseorang adalah kombinasi dari bagaimana ia menyerap dan kemudian mengatur, serta mengolah informasi. Gaya belajar yang dimiliki setiap siswa berbeda-beda. Siswa cenderung memilih gaya belajar yang sesuai dengan kemampuan siswa untuk memahami dan menyerap pelajaran. Ada yang cepat, 
sedang, dan ada pula yang lambat. Oleh karena itu, siswa sering kali harus menempuh cara berbeda untuk bisa memahami sebuah informasi atau pelajaran yang sama.

Siswa-siswa SMA yang ada di Makale juga memerlukan konsep diri, motivasi berprestasi, dan gaya belajar untuk menumbuhkan disposisi dan memperoleh hasil belajar matematika yang lebih baik. Siswa harus memiliki perasaaan dan keyakinan dalam dirinya terhadap matematika, daya dorong yang tinggi untuk belajar matematika, serta cara belajar yang tepat agar siswa tertarik dan bersikap positif terhadap matematika.

Berdasarkan uraian latar belakang di atas, maka penulis mengambil judul“" Pengaruh Konsep Diri, Motivasi Berprestasi, dan Gaya Belajar Terhadap Disposisi dan Hasil Belajar Matematika Siswa Kelas XI SMA Negeri di Kota Makale".

\section{METODE PENELITIAN}

Jenis penelitian ini adalah penelitian ex-post facto yang bersifat kausatif. Peneliti menelusuri hubungan sebab akibat dan menguji hipotesis yang telah dirumuskan konsep diri, motivasi berprestasi, gaya belajar terhadap disposisi matematika dan hasil belajar matematika. Adapun desain penelitian ini ditunjukkan pada Gambar 1 berikut:

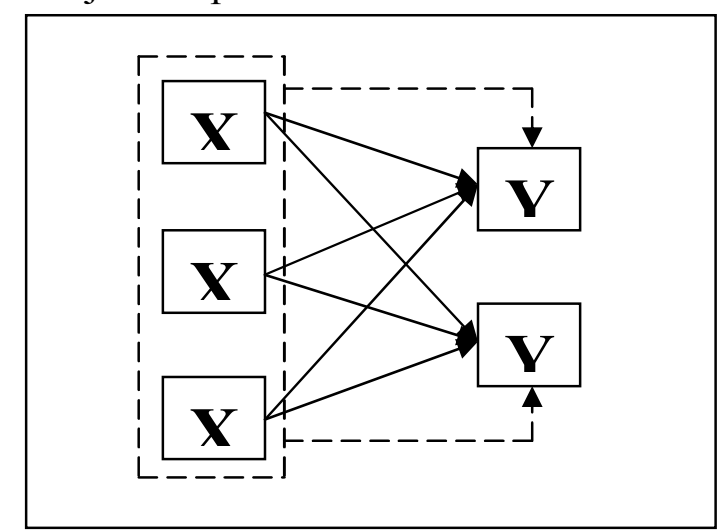

Keterangan:

$\mathrm{X}_{1}$ : konsep diri

$\mathrm{X}_{2}$ : motivasi berprestasi

$\mathrm{X}_{3}$ : gaya belajar

$\mathrm{Y}_{1}$ : disposisi matematika

$\mathrm{Y}_{2}$ : hasil belajar matematika

Gambar 1. Desain Penelitian

Populasi dalam penelitian ini adalah seluruh siswa Kelas XI IPA SMA Negeri di Kota Makale pada tahun pelajaran 2015/2016. Teknik pengambilan data menggunakan teknik cluster proporsional random sampling. Sampel dalam penelitian ini terdiri dari 171 siswa.

Variabel dalam penelitian ini terdiri dari tiga variabel bebas, yaitu: konsep diri, motivasi berprestasi, dan gaya belajar. Sedangkan, variabel terikatnya, yaitu: disposisi matematika dan hasil belajar matematika. Pengukuran terhadap konsep diri, motivasi berprestasi, dan disposisi matematika menggunakan Skala Likert dalam bentuk angket, gaya belajar dalam bentuk pernyataan, dan hasil belajar matematika dalam bentuk tes.

Konsep diri yang dikaitkan dengan konteks pembelajaran matematika, berdasarkan pada aspek konsep diri yaitu persepsi, kemampuan, sikap, hubungan dengan orang lain dan perasaan terhadap matematika. Motivasi berprestasi yang 
dikaitkan dengan konteks pembelajaran matematika, berdasarkan pada aspek motivasi berprestasi yaitu berusaha untuk unggul, menyelesaikan tugas dengan baik, rasional dalam meraih keberhasilan, menyukai tantangan, menerima tanggung jawab pribadi untuk sukses, dan menyukai situasi dengan tanggung jawab pribadi, umpan balik, dan resiko tingkat menengah (Djaali, 2012). Skala disposisi matematika dengan konteks pembelajaran matematika, berdasarkan pada aspek yaitu kepercayaan diri, kegigihan atau ketekunan, berpikir terbuka dan fleksibel, minat dan keingintahuan, serta memonitor dan mengevaluasi (Mahmudi, 2010). Gaya belajar ini terdiri dari 20 pernyataan yang terdiri dari tiga pilihan yang menyangkut gaya belajar visual, auditorial, dan kinestetik. Tes dalam penelitian ini dalam bentuk pilihan ganda.

Sebelum digunakan, instrumen di sahihasi dengan kesahihan isi dan kesahihan konstrak. Kesahihan isi dilakukan dengan meminta tanggapan kepada dua pakar. Sedangkan, kesahihan konstrak dilakukan dengan menggunakan kesahihan butir setelah pelaksanaan uji coba instrumen menurut Tiro dan Sukarna (2012), yaitu, uji kekonsistenan internal, uji kesahihan konstruk, dan menghitung koefisien keandalan.

Pengumpulan data dilakukan dengan memberikan instrumen kepada siswa yang menjadi sampel penelitian. Pengumpulan data dilakukan bertahap sesuai dengan rencana dan jadwal penelitian yang telah disepakati antara peneliti dengan pihak sekolah.

\section{HASIL PENELITIAN DAN PEMBAHASAN}

Hasil Penelitian

Analisis Deskriptif

Teknik analisis deskiptif digunakan untuk mendeskripsikan karakteristik skor responden penelitian untuk masing-masing kelompok peneliti seperti ratarata, modus, median, mean, standar deviasi dan perhitungan persentase. Data yang terkumpul dianalis dengan menggunakan analisis kuantitatif dan menggunakan statistik deskriptif. Analisis statistik deskriptif digunakan untuk mengetahui gambaran deskriptif konsep diri, motivasi berprestasi, dan gaya belajar dan hasil belajar matematika. Berdasarkan skor yang dicapai siswa, diperoleh hasil statistika deskripsi konsep diri, motivasi berprestasi, disposisi matematika, dan hasil belajar matematika siswa Kelas XI IPA SMA Negeri di Kota Makale seperti disajikan pada Tabel 1 berikut:

Tabel 1. Hasil Statistika Deskriptif Konsep Diri, Motivasi Berprestasi, Disposisi Matematika, dan Hasil Belajar Matematika 171 Siswa Kelas XI IPA SMA Negeri di Kota Makale

\begin{tabular}{|c|c|c|c|c|c|}
\hline \multirow[b]{2}{*}{ No } & \multirow[b]{2}{*}{ Statistik } & \multicolumn{4}{|c|}{ Nilai Statistik } \\
\hline & & $\begin{array}{c}\text { Konsep } \\
\text { Diri }\end{array}$ & $\begin{array}{c}\text { Motivasi } \\
\text { Berprestasi }\end{array}$ & $\begin{array}{c}\text { Disposisi } \\
\text { Matematika }\end{array}$ & $\begin{array}{l}\text { Hasil Belajar } \\
\text { Matematika }\end{array}$ \\
\hline 1 & Rata-rata & 107,18 & 145,55 & 110,77 & 56,59 \\
\hline 2 & Median & 108,00 & 147,00 & 111,00 & 56,67 \\
\hline 3 & Modus & 106,00 & 148,00 & 113,00 & 63,33 \\
\hline 4 & Standar & 11,95 & 16,69 & 11,04 & 20,74 \\
\hline
\end{tabular}




\begin{tabular}{rlrrrr}
\hline \hline & & & & \\
\hline & Deviasi & & & & \\
5 & Variansi & 142,82 & 278,65 & 121,77 & 430,32 \\
6 & Skewness & $-0,87$ & $-0,17$ & $-0,14$ & 0,14 \\
7 & Kurtosis & 0,12 & $-0,48$ & $-0,44$ & $-0,85$ \\
8 & Rentang & 65,00 & 78,00 & 58,00 & 76,67 \\
& Skor & 73,00 & 105,00 & 79,00 & 20,00 \\
& Minimum & & & 137,00 & 96,67 \\
10 & Skor & 138,00 & 183,00 & 13,00 & \\
& Maksimum & & & & \\
\hline
\end{tabular}

Berdasarkan pengklasifikasian gaya belajar, diperoleh distribusi gaya belajar siswa kelas XI IPA SMA Negeri di kota Makale seperti tampak pada Tabel 2 berikut:

Tabel 2. Distribusi Gaya Belajar 171 Siswa Kelas XI IPA SMA Negeri di Kota Makale

\begin{tabular}{ccrr}
\hline No & Gaya Belajar & Banyaknya Siswa & Persentase (\%) \\
\hline 1 & Visual & 103 & 60,2 \\
2 & Auditorial & 40 & 23,4 \\
3 & Kinestetik & 28 & 16,4 \\
\hline & Jumlah & 171 & 100 \\
\hline
\end{tabular}

Analisis Inferensial

Sebelum pengujian hipotesis secara inferensial maka terlebih dahulu dilakukan uji prasyarat analisis dengan uji normalitas dengan menggunakan uji Kolmologrof Smirnov dan uji multikolinearitas. Analisis yang digunakan dalam penelitian ini menggunakan regresi linear berganda. Namun demikian, dalam penelitian ini akan digunakan bantuan analisis sofwarwe SPSS 20. Selanjutnya untuk menguji hipotesis tentang pengaruh konsep diri, motivasi berprestasi dan gaya belajar terhadap disposisi matematika dapat dilihat pada Tabel 3 berikut:

Tabel 3. Peubah untuk Konsep Diri, Motivasi Berprestasi dan Gaya Belajar terhadap

Disposisi Matematika

\begin{tabular}{|c|c|c|c|c|c|}
\hline \multirow{2}{*}{ Model } & \multicolumn{2}{|c|}{$\begin{array}{c}\text { Unstandardized } \\
\text { Coefficients }\end{array}$} & \multirow{2}{*}{$\begin{array}{c}\begin{array}{c}\text { Standardized } \\
\text { Coefficients }\end{array} \\
\text { Beta }\end{array}$} & \multirow{2}{*}{$\mathbf{t}$} & \multirow[b]{2}{*}{$p$} \\
\hline & B & $\begin{array}{c}\text { Kesalahan } \\
\text { Baku }\end{array}$ & & & \\
\hline (Constant) & 37,451 & 5,671 & & 6,604 & $<0,001$ \\
\hline Konsep diri & 0,267 & 0,077 & 0,289 & 3,479 & 0,001 \\
\hline Motivasi berprestasi & 0,312 & 0,055 & 0,472 & 5,705 & $<0,001$ \\
\hline Gaya belajar auditotrial & $-2,247$ & 1,453 & $-0,086$ & $-1,546$ & 0,124 \\
\hline Gaya belajar kinestetik & $-1,135$ & 1,671 & $-0,038$ & $-0,679$ & 0,498 \\
\hline
\end{tabular}


Berdasarkan Tabel 3 diperoleh nilai t untuk konsep diri adalah 3,479 dengan nilai $p=0,001$ pada taraf signifikan $\alpha>0,05$ maka diputuskan $\mathrm{H}_{0}$ ditolak. Artinya konsep diri berpengaruh positif terhadap disposisi matematika siswa Kelas XI IPA SMA Negeri di Kota Makale dengan nilai koefisien Beta $=0,289$. Artinya konsep diri memberikan konstribusi sebanyak 28,9\% terhadap disposisi dan sisanya $71,1 \%$ disposisi matematika ditentukan oleh variabel lain.

Berdasarkan Tabel 3 diperoleh nilai $\mathrm{t}$ untuk motivasi berprestasi adalah 5,705 dengan nilai $p<0,001$ pada taraf signifikan $\alpha>0,05$ maka diputuskan $\mathrm{H}_{0}$ ditolak. Artinya motivasi berprestasi berpengaruh positif terhadap disposisi matematika siswa Kelas XI IPA SMA Negeri di Kota Makale dengan nilai koefisien Beta $=0,472$. Artinya motivasi berprestasi memberikan konstribusi sebanyak 47,2\% terhadap disposisi matematika dan sisanya 52,8\% disposisi matematika ditentukan oleh variabel lain.

Berdasarkan Tabel 3 diperoleh nilai t untuk gaya belajar auditorial adalah -1,546 dengan nilai $p=0,124$ dan nilai t untuk gaya belajar kinestetik adalah 0,679 dengan nilai $p=0,498$ yang berarti tidak signifikan, maka diputuskan $\mathrm{H}_{0}$ diterima, artinya bahwa tidak ada pengaruh gaya belajar terhadap disposisi matematika siswa Kelas XI IPA SMA Negeri di Kota Makale. Nilai koefisien Beta untuk gaya belajar auditorial adalah $-0,086$ dan gaya belajar kinestetik adalah -0,038. Artinya gaya belajar memberikan konstribusi sebesar $1 \%$ terhadap disposisi matematika dan sisanya 99\% ditentukan oleh variabel lain. Adapun besarnya korelasi antara konsep diri, motivasi berprestasi dan gaya belajar dengan disposisi matematika siswa disajikan dalam Tabel 4 berikut:

Tabel 4. Koefisien Determinasi dengan Disposisi Matematika

\begin{tabular}{ccccc}
\hline Model & $\mathrm{R}$ & R Kuadrat & $\begin{array}{c}\text { R Kuadrat } \\
\text { Terkoreksi }\end{array}$ & $\begin{array}{c}\text { Nilai Kesalahan } \\
\text { Baku }\end{array}$ \\
\hline $\mathbf{1}$ & $0,719^{\mathrm{a}}$ & 0,518 & 0,506 & 7,756 \\
\hline
\end{tabular}

Berdasarkan Tabel 4. diperoleh daya ramal model sebesar 0,518. Jadi model mempunyai daya ramal $52 \%$ (variasi disposis matematika dapat dijelaskan oleh model). Sedang koefisien determinasi ( $\mathrm{R}^{2}$ terkoreksi) sebesar 0,506. Angka tersebut menunjukkan bahwa konsep diri, motivasi berprestasi dan gaya belajar, secara bersama-sama dapat menjelaskan sekitar 51\% variasi disposisi matematika siswa Kelas XI IPA SMA Negeri di Kota Makale dan sisanya 49\% disebabkan oleh faktor lain yang tidak diselidiki dalam penelitian ini. Selanjutnya untuk menguji hipotesis tentang pengaruh konsep diri, motivasi berprestasi dan gaya belajar terhadap hasil belajar matematika dapat dilihat pada Tabel 5 berikut:

Tabel 5. Peubah Untuk Konsep Diri, Motivasi Berprestasi Dan Gaya Belajar Terhadap Hasil Belajar Matematika

\begin{tabular}{|c|c|c|c|c|c|}
\hline \multirow{2}{*}{ Model } & \multicolumn{2}{|c|}{$\begin{array}{c}\text { Unstandardized } \\
\text { Coefficients }\end{array}$} & \multirow{2}{*}{$\begin{array}{c}\begin{array}{c}\text { Standardized } \\
\text { Coefficients }\end{array} \\
\text { Beta }\end{array}$} & \multirow{2}{*}{$\mathrm{t}$} & \multirow[b]{2}{*}{$p$} \\
\hline & B & $\begin{array}{c}\text { Kesalahan } \\
\text { Baku }\end{array}$ & & & \\
\hline (Constant) & 26,805 & 15,055 & & 1,780 & 0,077 \\
\hline Konsep diri & 0,043 & 0,204 & 0,025 & 0,209 & 0,835 \\
\hline Motivasi berprestasi & 0,185 & 0,145 & 0,149 & 1,273 & 0,205 \\
\hline
\end{tabular}




\begin{tabular}{llllll} 
Gaya belajar auditorial & $-4,691$ & 3,858 & $-0,096$ & $-1,216$ & 0,226 \\
Gaya belajar kinestetik & $-3,545$ & 4,435 & $-0,799$ & $-0,799$ & 0,425 \\
\hline
\end{tabular}

Berdasarkan Tabel 5 diperoleh nilai t untuk konsep diri adalah 0,209 dengan nilai $p=0,835$ pada taraf signifikansi $\alpha>0,05$ maka diputuskan $\mathrm{H}_{0}$ diterima. Artinya konsep diri tidak berpengaruh positif terhadap hasil belajar matematika siswa Kelas XI IPA SMA Negeri di Kota Makale dengan nilai koefisien Beta adalah 0,025. Artinya konsep diri memberikan konstribusi sebanyak 2,5\% terhadap hasil belajar matematika dan sisanya $97,5 \%$ hasil belajar matematika ditentukan oleh variabel lain.

Berdasarkan Tabel 5 diperoleh nilai t untuk motivasi berprestasi adalah 1,273 dengan nilai $p=0,205$ pada taraf signifikansi $\alpha=0,05$ maka diputuskan $\mathrm{H}_{0}$ diterima. Artinya motivasi berprestasi tidak berpengaruh positif terhadap hasil belajar matematika siswa Kelas XI IPA SMA Negeri di Kota Makale dengan nilai koefisien Beta adalah 0,149. Artinya motivasi berprestasi memberikan konstribusi sebanyak $14,9 \%$ terhadap hasil belajar matematika dan sisanya $85,1 \%$ hasil belajar matematika ditentukan oleh variabel lain.

Berdasarkan Tabel 5 diperoleh diperoleh nilai $\mathrm{t}$ untuk gaya belajar auditorial adalah $-1,216$ dengan nilai $p=0,226$ dan nilai $t$ untuk gaya belajar kinestetik adalah $-0,799$ dengan nilai $p=0,425$ yang berarti tidak signifikan, maka diputuskan $\mathrm{H}_{0}$ diterima, artinya bahwa tidak ada pengaruh gaya belajar terhadap hasil belajar matematika siswa Kelas XI IPA SMA Negeri di Kota Makale. Nilai koefisien Beta untuk gaya belajar auditorial adalah -0,096 dan gaya belajar kinestetik adalah $-0,799$. Artinya gaya belajar memberikan konstribusi sekitar 1\% terhadap hasil belajar matematika dan sisanya 99\% ditentukan oleh variabel lain. Adapun besarnya korelasi antara konsep diri, motivasi berprestasi dan gaya belajar dengan hasil belajar matematika siswa disajikan dalam Tabel 6 berikut:

Tabel 6. Koefisien Determinasi dengan Hasil Belajar Matematika

\begin{tabular}{ccccc}
\hline Model & R & R Kuadrat & $\begin{array}{c}\text { R Kuadrat } \\
\text { Terkoreksi }\end{array}$ & Nilai Kesalahan Baku \\
\hline 2 & $0,195^{\text {a }}$ & 0,038 & 0,015 & 20,590 \\
\hline
\end{tabular}

Berdasarkan Tabel 6 diperoleh daya ramal model sebesar 0,038. Jadi, model mempunyai daya ramal $4 \%$ (variasi $\mathrm{Y}$ dapat dijelaskan oleh model). Sedangkan koefisien determinasi $\left(\mathrm{R}^{2}\right.$ terkoreksi) sebesar 0,015. Angka tersebut menunjukkan bahwa konsep diri, motivasi berprestasi dan gaya belajar,secara bersama-sama dapat menjelaskan sekitar $2 \%$ variasi hasil belajar matematika siswa Kelas XI IPA SMA Negeri di Kota Makale dan sisanya 98\% disebabkan oleh faktor lain yang tidak diselidiki dalam penelitian ini.

\section{PEMBAHASAN}

Berdasarkan skor yang dicapai siswa pada umumnya konsep diri, motivasi berprestasi, disposisi matematika dan hasil belajar matematika siswa Kelas XI IPA SMA Negeri di Kota Makale berada pada kategori sedang. Sedangkan 
berdasarkan pengklasifikasian gaya belajar siswa Kelas XI IPA SMA Negeri di Kota Makale adalah gaya belajar visual.

Berdasarkan pengujian hipotesis tentang pengaruh konsep diri terhadap disposisi matematika siswa Kelas XI IPA SMA Negeri di Kota Makale, diputuskan Ho ditolak yang berarti bahwa konsep diri berpengaruh positif terhadap disposisi matematika dengan konstribusi $28,9 \%$. Siswa yang memiliki konsep diri yang tinggi tentunya penuh dengan rasa percaya diri dalam belajar matematika. Polking (Sumarmo, 2013) mengemukakan bahwa disposisi matematika menunjukkkan rasa percaya diri dalam menggunakan matematika, memecahkan masalah, memberi alasan dan mampu mengkomunikasikan gagasan dalam pelajaran matematika. Silver (Sumarmo, 2013) mengemukakan rasa percaya diri merefleksikan bagaimana seseorang berpikir tentang sesuatu. Sikap positif ditunjukkan dengan semangat belajar, penuh perhatian, saling sumbang saran, dan saling menghormati sesama. Sebaliknya, sikap negatif ditunjukkan dengan rasa tidak suka, tidak tertarik, tidak berminat, dan cemas terhadap matematika.

Berdasarkan pengujian hipotesis tentang pengaruh konsep diri terhadap hasil belajar matematika siswa Kelas XI IPA SMA Negeri di Kota Makale, diputuskan Ho diterima yang berarti bahwa konsep diri tidak berpengaruh positif terhadap hasil belajar matematika siswa dengan konstribusi 2,5\%. Berdasarkan hasil penelitian, peneliti menduga adanya kemungkinan hasil penelitian ini dikarenakan tingginya skor hasil belajar matematika yang diperoleh dari hasil pekerjaan siswa masing-masing sekolah yang menjadi lokasi penelitian, namun tidak diimbangi dengan skor konsep diri yang diperoleh dari hasil pengisian angket konsep diri oleh siswa.

Berdasarkan pengujian hipotesis tentang pengaruh motivasi berprestasi terhadap disposisi matematika siswa Kelas XI IPA SMA Negeri di Kota Makale, diputuskan Ho ditolak yang berarti bahwa motivasi berprestasi berpengaruh positif terhadap disposisi matematika siswa dengan konstribusi 47,2\%. Siswa yang memiliki motivasi berprestasi yang tinggi tentunya penuh kegigihan atau ketekunan untuk belajar dengan baik untuk memuaskan kebutuhan. Kebutuhan untuk berprestasi adalah dorongan untuk menjadi lebih baik (Boyatzis, 2000). Dengan adanya dorongan ini mereka ingin menyelesaikan tugasnya dengan baik, dan berusaha untuk tampil lebih baik berdasarkan patokan standar yang mereka buat. Sedangkan siswa yang motivasinya rendah justru berperilaku sebaliknya. Menurut McCleland bahwa kita semua memiliki dorongan ini dengan kadar yang berbeda-beda satu sama lain dan terus berubah dari waktu ke waktu (Moore, dkk, 2010).

Berdasarkan pengujian hipotesis tentang pengaruh motivasi berprestasi terhadap tes hasil belajar matematika siswa Kelas XI IPA SMA Negeri di Kota Makale, diputuskan Ho diterima, yang berarti bahwa motivasi berprestasi tidak berpengaruh positif dengan konstribusi 14,9 \% Berdasarkan hasil penelitian, peneliti menduga adanya kemungkinan hasil penelitian ini dikarenakan tingginya skor hasil belajar matematika yang diperoleh dari hasil pekerjaan siswa masingmasing sekolah yang menjadi lokasi penelitian, namun tidak diimbangi dengan 
skor motivasi berprestasi yang diperoleh dari hasil pengisian angket motivasi berprestasi oleh siswa.

Berdasarkan pengujian hipotesis tentang pengaruh gaya belajar terhadap disposisi matematika dan hasil belajar matematika siswa Kelas XI IPA SMA Negeri di Kota Makale, diputuskan Ho diterima, yang berarti bahwa gaya belajar tidak berpengaruh terhadap disposisi matematika dengan konstribusi sekitar $1 \%$. Hal ini mengindikasikan bahwa baik gaya belajar visual, auditorial, dan kinestetik tidak memiliki pengaruh terhadap disposisi matematika dan hasil belajar matematika siswa Kelas XI IPA SMA Negeri di Kota Makale. Pada awal pengalaman belajar, salah satu diantara langkah pertama adalah mengenali modalitas atau gaya belajar yang dimiliki, apakah gaya belajar visual, gaya belajar auditorial, dan gaya belajar kinestetik (Hasrul, 2009). Ketiga gaya dan tipologi belajar tersebut, tidak memberikan arti bahwa setiap individu atau seseorang hanya memiliki satu cara dan tipe belajar tertentu sehingga tidak memiliki cara dan tipe belajar yang lain (Bire, dkk. 2014). Orang-orang berbakat tampaknya dapat belajar dengan cara yang sama baik secara visual, auditorial, dan kinestetik (Hasrul, 2009). Hal ini dapat dilakukan dengan meminimalisir kekurangankekurangan dari setiap gaya belajar yang ada. Hasil penelitian yang menunjukkan bahwa gaya belajar mempunyai pengaruh yang sama relevan dengan hasil penelitian terdahulu yang dilakukan oleh Riani, (2014) yang menyatakan bahwa ketiga gaya belajar tersebut memiliki pengaruh yang sama terhadap prestasi belajar matematika.

Berdasarkan pengujian hipotesis tentang pengaruh konsep diri, motivasi berprestasi dan gaya belajar terhadap disposisi matematika dan hasil belajar matematika siswa Kelas XI IPA SMA Negeri di Kota Makale, diputuskan Ho diterima yang artinya konsep diri, motivasi berprestasi dan gaya belajar secara bersama-sama tidak berpengaruh terhadap disposisi matematika dan hasil belajar matematika.

Konsep diri, motivasi berprestasi, dan gaya belajar secara bersama-sama tidak berpengaruh terhadap disposisi matematika dan hasil belajar matematika siswa Kelas XI IPA SMA Negeri di Kota Makale maka dalam penelitian ini mengalami pengembangan pembahasan dengan menggunakan analisis jalur (path analysis). Pengembangan pembahasan ini menggunakan metode ellips. Metode ellips adalah suatu paradigma dalam memandang cara menganalisis data kuantitatif dan bisa dianggap sebagai konsep dan pandangan filosofis terhadap berbagai teknik analisis data (Tiro dan Sukarna, 2013). Variabel-variabel yang digunakan dalam pengembangan pembahasan ini adalah konsep diri, motivasi berprestasi, disposisi matematika, dan hasil belajar matematika. Variabel gaya belajar tidak digunakan karena merupakan data kategori. Adapun desain dengan menggunakan metode ellips dapat dilihat pada Gambar 2 berikut: 


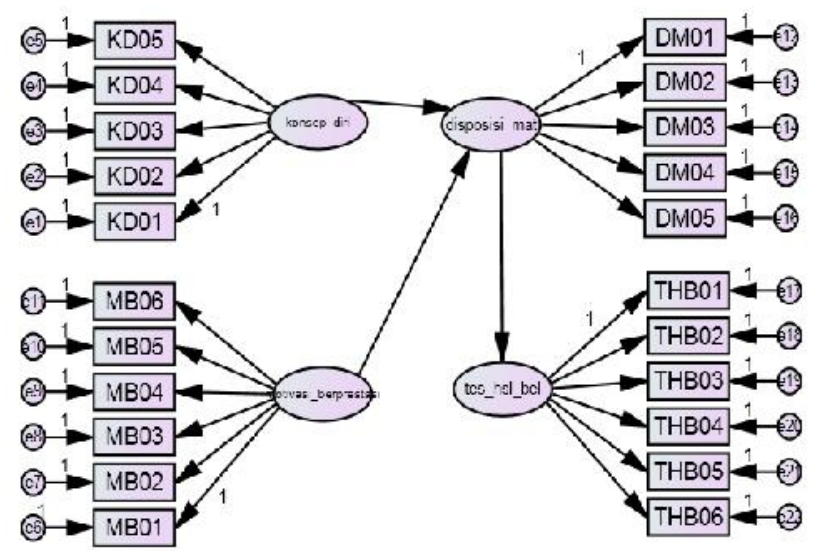

Gambar 2. Analisis Jalur dengan menggunakan Metode Ellips

Selanjutnya untuk menguji tentang pengaruh konsep diri dan motivasi berprestasi terhadap hasil belajar matematika melalui disposisi matematika dapat dilihat pada Tabel 7 berikut:

Tabel 7. Koefisisen Jalur Tidak Terbakukan (Metode Ellips)

\begin{tabular}{ccccccc}
\hline & & & Taksiran & $\begin{array}{c}\text { Kesalahan } \\
\text { Baku }\end{array}$ & $\begin{array}{c}\text { Koefisien } \\
\text { Perbandingan }\end{array}$ & $\boldsymbol{p}$ \\
\hline disposisi_mat & $<---$ & konsep_diri & 0,454 & 0,092 & 4,916 & $<\mathbf{0 , 0 0 1}$ \\
disposisi_mat & $<---$ & motivasi_berprestasi & 0,305 & 0,060 & 5,082 & $<\mathbf{0 , 0 0 1}$ \\
tes_hsl_bel & $<---$ & disposisi_mat & 0,323 & 0,137 & 2,357 & $\mathbf{0 , 0 1 8}$ \\
\hline
\end{tabular}

Berdasarkan Tabel 7 menunjukkan koefisien yang berpengaruh langsung dari konsep diri terhadap disposisi sebesar 0,454. Sedangkan, koefisien motivasi berprestasi terhadap disposisi matematika berpengaruh langsung sebesar 0,305. Selanjutnya, koefisien pengaruh tidak langsung konsep diri terhadap hasil belajar matematika adalah $(0,454) .(0,323)=0,147$, sedangkan koefisien pengaruh tidak langsung motivasi berprestasi terhadap hasil belajar matematika adalah $(0,305) .(0,323)=0,099$. Kontribusi variabel konsep diri terhadap hasil belajar matematika melalui disposisi matematika sekitar 15\%. Selanjutnya, kontribusi variabel motivasi berprestasi terhadap hasil belajar matematika melalui disposisi matematika sekitar 10\%. Jadi, dapat disimpulkan bahwa konsep diri memberikan konstribusi terbesar terhadap hasil belajar matematika melalui disposisi matematika siswa SMA Negeri di Kota Makale. Menurut Syam (2012) bahwa orang yang memiliki konsep diri positif akan lebih optimis, percaya diri, dan selalu bersikap positif terhadap sesuatu, termasuk dalam menghadapi kegagalan yang dialaminya, serta melakukan sesuatu demi keberhasilan di masa depan. Ini berarti, siswa yang mempunyai konsep diri yang baik ditunjang dengan sikap positif akan memberikan prestasi atau hasil belajar matematika yang baik.

\section{DAFTAR PUSTAKA}

Arifin, Zainal. 2011. Evaluasi Pembelajaran. Bandung: Remaja Rosdakarya. 
Ayodele, J. O. 2011. Self-Concept and Performance of Secondary School Students in Mathematics. Jurnal Institute of Education University of AdoEkiti

(http://www.ccsenet.org/journal/index.php/jedp/article/download/13911/9 570, Diakses 20 Oktober 2015).

Bire, Arylien Ludji., Geradus, Uda \& Bire, Josua. 2014. Pengaruh Gaya Belajar Visual, Auditorial, dan Kinestetik Terhadap Prestasi Belajar Siswa. Jurnal Kependidikan, Volume 44, Nomor 2. NTT: Universitas Nusa Cendana.

Boyatzis R.E.2000. David C.McClelland: Biographical Statement and Synopsis of His Work. Weatherhead School of Mgt. Case Western Reserve University August 15,2000. University in Cleveland, Ohio.

Deporter, Bobbi. 2003. Quantum Learning. Bandung : Kaifa.

Djaali. 2012. Psikologi Pendidikan. Jakarta: Bumi Aksara.

Hartuti, dkk. 2012. Undang-Undang RI Tahun 2003. Yogyakarta: Laksana.

Hasrul. 2009. Pemahaman Tentang Gaya Belajar. Jurnal Medtek, Volume 1, Nomor 2. Makassar: Fakultas Teknik UNM.

Mahmudi, Ali (2010). Pengaruh Pembelajaran dengan Strategi MHM Berbasis Masalah terhadap Kemampuan Berpikir Kreatif, Kemampuan Pemecahan Masalah, dan Disposisi Matematis, serta Persepsi terhadap Kreativitas. Disertasi. Universitas Pendidikan Indonesia.

Moore,L.L., Grabsch, D.K \&, Rotter C..2010. Using Achivement Motivation Theory to Explain Student Participation in a Residential Leadership Learning Community. Journal of Leadership Education. Volume 9, Issue 2:22-34.

Riani, Erna. 2014. Pengaruh Gaya Belajar Terhadap Prestasi Belajar Siswa pada Mata Mata Pelajaran Matematika Kelas VII SMP. Jurnal. Universitas Muhammadiyah Purworejo.

Saam, Z \& Wahyuni, S. 2012. Psikologi Keperawatan. Jakarta: Rajawali Pers.

Suciati, I. 2013. Pengaruh Sosioemosi Dan Perkembangan Moral terhadap Hasil Belajar Matematika Siswa Kelas XI SMA Negeri Di Kota Palu. Tesis magister (tidak diterbitkan). PPs Universitas Negeri Makassar.

Suherman, dkk. 2003. Strategi Pembelajaran Matematika Kontemporer. Bandung: JICA.

Sumarmo, Utari. 2013. Berpikir dan Disposisi Matematika serta Pembelajarannya. Bandung: FMIPA Universitas Pendidikan Indonesia.

Syam, N. W. 2012. Psikologi Sosial sebagai Akar Ilmu Komunikasi. Bandung: Simbiosa Rekatama Media.

Tiro, M. A. \& Sukarna. 2012. Pengembangan Instrumen Pengumpulan Data Penelitian. Makassar: Andira Publisher. . 2013. Metode Ellips dalam Analisis Data Kuantitatif: Andira Publisher.

Uno, Hamzah. 2012. Teori Motivasi dan Pengukurannya. Jakarta: Bumi Aksara.

Wardani, S. 2013. Teknik Pengembangan Instrumen Penilaian Hasil Belajar Matematika. Yogyakarta: PPPPTK 